\title{
Article \\ Plant Diversity and Soil Nutrients in a Tropical Coastal Secondary Forest: Association Ordination and Sampling Year Differences
}

\author{
Muhammad Yaseen ${ }^{1,2,3}$, Gaopan Fan ${ }^{4}$, Xingcui Zhou ${ }^{4}$, Wenxing Long ${ }^{1,2,3, *}$ and Guang Feng ${ }^{1,2,3}$ \\ 1 College of Ecology and Environment, Hainan University, Haikou 570228, China; \\ 20181112909153@hainanu.edu.cn (M.Y.); 995100@hainanu.edu.cn (G.F.) \\ 2 Wuzhishan National Long-Term Forest Ecosystem Monitoring Research Station, College of Forestry, \\ Hainan University, Haikou 570100, China \\ 3 Administration of Tongguling National Nature Reserve, Wenchang 571300, China \\ 4 Key Laboratory of Tropical Forest Flower Genetics and Germplasm Innovation, Ministry of Education, \\ Haikou 570228, China; fangaopan53418368@163.com (G.F.); xingcui847876096@163.com (X.Z.) \\ * Correspondence: oklong@hainanu.edu.cn
}

check for

updates

Citation: Yaseen, M.; Fan, G.;

Zhou, X.; Long, W.; Feng, G. Plant

Diversity and Soil Nutrients in a

Tropical Coastal Secondary Forest:

Association Ordination and Sampling

Year Differences. Forests 2022, 13, 376.

https://doi.org/10.3390/f13030376

Academic Editors: Yi Ding,

Runguo Zang and

Timothy A. Martin

Received: 5 December 2021

Accepted: 12 February 2022

Published: 24 February 2022

Publisher's Note: MDPI stays neutral with regard to jurisdictional claims in published maps and institutional affiliations.

Copyright: (c) 2022 by the authors. Licensee MDPI, Basel, Switzerland. This article is an open access article distributed under the terms and conditions of the Creative Commons Attribution (CC BY) license (https:// creativecommons.org/licenses/by/ $4.0 /)$.

\begin{abstract}
Studying the patterns of changes in species diversity and soil properties can improve our knowledge of community succession. However, there is still a gap in understanding how soil conditions are related to plant diversity in tropical coastal secondary forests. We sampled plant diversity and soil nutrients spanning two different years (2012 and 2019) to assess the patterns of species diversity and relationships of soil nutrients and species diversity on Hainan Island, southern China. Results showed that the soil $\mathrm{pH}$ and total nitrogen (TN) significantly decreased while the soil organic matter (OM) and total phosphorus (TP) significantly increased from 2012 to 2019. Plant species diversity was significantly higher in 2012 than in 2019, and the dominant species significantly changed in two different years. Using multiple regression analysis, we determined that soil TP and TN were significantly related to plant diversity in 2012 and 2019, respectively. Using CCA analysis, TN and OM were the strongest predictors for dominant species in 2012, whereas the soil TP and TN were the strongest predictors for dominant species in 2019. Our findings show a significant change in plant diversity and dominant species after 7 years of development in the tropical coastal secondary forest. The patterns of plant diversity and soil nutrients increase our knowledge of forest restoration in coastal areas.
\end{abstract}

Keywords: soil nutrients; plant diversity; regression dominant species; tropical monsoonal forest

\section{Introduction}

Tropical forests tend to have a high level of biodiversity and aboveground biomass, and they grow on strongly weathered soils. Even within a tropical region, the distribution of plant species and soils is highly diverse [1]. Plant-soil interaction is a key internal driver of ecosystem evolution. The unidirectional effects of soil nutrients on plant diversity have been described in many studies [2]. Environmental factors such as climate, soil characteristics, and herbivory have significantly influenced plant diversity [3,4], and plant community growth is heavily dependent on soil nutrient availability [5]. Plant community features such as plant biomass, vegetation cover, and species composition can be affected due to changes in soil nutrients [6], resulting in compositional dissimilarity at the local, landscape, and regional scales. However, there are still many gaps in our knowledge about how soil nutrients affect tree species diversity in tropical forests [7].

From grassland to primary forest, an increase in organic matter (OM) and total nitrogen (TN) may have a positive effect on species diversity and lead to increased species richness [8]. Despite low P availability in tropical forests, many low-P specialists have indicated that plants can maintain high growth rates [9] and exhibit muted responses due 
to $\mathrm{P}$ addition [10]. Conversely, high-P specialists have revealed that plants have much stronger responses due to $\mathrm{P}$ addition [10]. Soil properties influenced the existence and quantity of dominating species in a tropical forest [11]. Limited resources either increase the species richness such as the dominating species by reducing their competitive strength [12] or decrease species richness by allowing a smaller number of species to endure the environment [12]. Long et al. [13] found the greatest effects of soil nutrients OM, P, N, and potassium $(\mathrm{K})$ on dominant species in two different vegetation sites, forest and shrub. However, we still lack a fundamental understanding of their causes and implications [14].

According to many recent studies on tropical forests, plant species richness is positively associated with soil nutrient concentration [15]. Plant species diversity and soil content of extractable phosphorus and potassium concentrations in the soil were discovered to have a positive relationship [16]. A high positive relationship was found between tree species richness and soil abiotic properties, i.e., nitrogen, phosphorus, and carbon concentrations in a dry deciduous forest in western India [17]. Previous studies reported that lack of soil nutrients [18] can affect the forest community structure. Contrarily, several studies have shown contradictory results [19]. Therefore, in-depth studies must be conducted, especially in tropical areas. In general, low soil nutrients and $\mathrm{pH}$ may be limiting factors for the loss of species diversity [20]. Soils in neotropical forests have been linked to differences in soil P limitation of plant growth [21]. It is demonstrated that differences in soil properties are mechanistically linked to plant biomass [22]. Soil $\mathrm{N}$ and $\mathrm{P}$ are major regulators of species richness, evenness, and community composition [23]. The effects of soil $\mathrm{N}$ and soil $\mathrm{P}$ on plant community structure appear to be distinct [24]. Available soil $\mathrm{N}$ has a positive association with the plant Simpson index [25], and soil P plays a significant role in producing and maintaining plant diversity [26].

Tropical coastal forests are typical of Hainan Island, off southern China's northeastern coast. Before 111 B.C., Hainan's forest cover reached 90\% [27]. However, the forests have been severely affected by anthropogenic factors (slash and burn) and natural disasters such as typhoons [13]. Tongguling National Nature Reserve (TNNR) is located at the land-sea junction in Wenchang County of Hainan Province, surrounded by sea on three sides. This tropical coastal forest is a natural forest flora in southern China with a small number of parallel ecosystems [28]. Therefore, biodiversity conservation, natural environmental monitoring, and typhoon mitigation are critical issues in this region [13]. However, little is known about changes in forest diversity and soil conditions over different periods of time. We collected a large data set including (a) species abundance and dominance and (b) soil abiotic properties in a tropical monsoonal dwarf forest. We used plant diversity and soil nutrient data for two different years and the following questions were addressed: (1) How did species diversity, dominant species abundance, and soil abiotic properties change in 7 years? (2) Did soil nutrients influence the plant diversity and abundance of dominant species? We predicted that the richness and abundance would increase in the two different years. These variations might be associated with changes in forest ecosystem resources and the quality of soil abiotic properties [29].

\section{Material and Methods}

\subsection{Site Conditions}

The present study was carried out in the TNNR $19^{\circ} 36^{\prime}-19^{\circ} 41^{\prime} \mathrm{N}, 110^{\circ} 58^{\prime}-111^{\circ} 03^{\prime} \mathrm{E}$ across the northeastern part of Hainan Island in southern China. TNNR is a $44 \mathrm{~km}^{2}$ wide natural reserve located at $338 \mathrm{~m}$ above sea level with a tropical monsoonal climate. The rainy season lasts from May to October, whereas the dry season lasts from November to April of the following year. The average annual temperature is $23.9^{\circ} \mathrm{C}$, with $1721.6 \mathrm{~mm}$ of rainfall. The tropical evergreen monsoonal forest possesses lateritic soil type [30]. Before 1980, all of these forests were deforested and converted to shrubs or secondary forests. After the establishment of TNNR in 1983, deforestation was prohibited, and forests were well recovered. 


\subsection{Data Collection}

We randomly established nine $50 \times 50 \mathrm{~m}\left(2500 \mathrm{~m}^{2}\right)$ plots in the tropical evergreen monsoonal forests in TNNR, with the distance between any two plots greater than $50 \mathrm{~m}$. Each plot was divided into 64 subplots of $20 \times 20 \mathrm{~m}\left(400 \mathrm{~m}^{2}\right)$ by the community size. The following criteria were used for plot selection: (a) common age of vegetation; (b) common comparison of the soil, geography, and original vegetation; and (c) without obvious additional interference. The background of each plot recovery was carried out based on official records of the forestry department or interviews with local communities. In 2012 and 2019, we conducted ground surveys to collect data on plant diversity and soil conditions. The two investigations were carried out by the same research group and kept a consistent method. Woody plants with a diameter at breast height (DBH) (i.e., $1.3 \mathrm{~m}$ of the stem from the ground) $\geq 1 \mathrm{~cm}$ were identified, tagged, and mapped. The DBH information of the sampled trees was collected using a measuring tape and tree height was measured using a laser rangefinder (Impulse 200, Laser Technology, Inc., Centennial, CO, USA). Flora of the Republic of China assisted in the identification of species [31].

During the rainy season (August) of 2012 and 2019, soil pH, TN, soil OM, and soil TP were measured by our research group. In each $20 \times 20 \mathrm{~m}\left(400 \mathrm{~m}^{2}\right)$ plot, four soil profiles were selected at random and sampled. A topsoil sample $(0-20 \mathrm{~cm})$ was taken from each soil profile after the trash or grass layer above the soil was carefully removed [32] along the diagonal of each $400 \mathrm{~m}^{2}$ plot. Each soil sample was ground and sieved to $2 \mathrm{~mm}$, lightly mixed, and analyzed following [33] with minor modifications.

\subsection{Soil Analysis}

For the measure of $\mathrm{OM}$ concentration, $0.5 \mathrm{~g}$ of soil was mixed with $5 \mathrm{~mL}$ of $1 \mathrm{~N}$ potassium dichromate $\left(\mathrm{K}_{2} \mathrm{Cr}_{2} \mathrm{O}_{7}\right)$ solution and $5 \mathrm{~mL}$ of $98 \%$ sulfuric acid $\left(\mathrm{H}_{2} \mathrm{SO}_{4}\right)$ and then kept at room temperature for half an hour. Second, deionized water and concentrated phosphoric acid $\left(\mathrm{H}_{3} \mathrm{PO}_{4}\right)$ were added followed by an amalgamation titration with $0.5 \mathrm{~mol} \mathrm{~L}^{-1}$ ferrous ammonium sulfate $\left.\left(\mathrm{NH}_{4}\right)_{2} \mathrm{Fe}\left(\mathrm{SO}_{4}\right)_{2} \cdot 6 \mathrm{H}_{2} \mathrm{O}\right)$ solution until the color changed from purple-blue to green. Finally, the titration was repeated until the color changed to green from violet-blue.

For the measure of $\mathrm{pH}$ concentration, $25 \mathrm{~g}$ of soil was added to de-ionized water and carefully stirred. Second, $\mathrm{pH}$ of suspension was measured using the $\mathrm{pH}$ electrode (Phoenix Electrode Company, Houston, TX, USA) at temperatures ranging from $20{ }^{\circ} \mathrm{C}$ to $25^{\circ} \mathrm{C}$.

For the measure of TN concentration, $1.0 \mathrm{~g}$ of soil was digested in $98 \%$ sulfuric acid $\left(\mathrm{H}_{2} \mathrm{SO}_{4}\right)$ with potassium sulfate, copper sulfate $\left(\mathrm{K}_{2} \mathrm{SO}_{4}-\mathrm{CuSO}_{4} \times 5\right)$, and hydroxy selenide $\left(\mathrm{H}_{2} \mathrm{O}-\mathrm{Se}\right)$. Secondly, ammonium nitrogen in the digest was extracted using steam with an excess of $0.1 \mathrm{~mol} \mathrm{~L}^{-1}$ sodium hydroxide $(\mathrm{NaOH})$ to increase the $\mathrm{pH}$ value. Thirdly, the distillate was obtained in $2 \% \mathrm{H}^{3} \mathrm{BO}^{3}$ and titration was conducted with $0.05 \mathrm{H}_{2} \mathrm{SO}_{4}$ to obtain a pH of 5.0. Finally, the TN concentration was calculated as per the volume change of a $0.05 \mathrm{M}$ sulfuric acid $\left(\mathrm{H}_{2} \mathrm{SO}_{4}\right)$ solution.

For the measure of TP concentration, $0.25 \mathrm{~g}$ of soil was mixed with $60 \% \mathrm{HClO}_{4}$ solution. Second, the mixture was diluted with a vanadium molybdate reagent, standard, and sampled at $700 \mathrm{~nm}$ wavelength. Third, the calibration curve was used to determine TP.

\subsection{Data Analysis}

The Shannon-Wiener index $(H)$, Pielou's evenness index $(E)$, and species richness were used to calculate the plant species diversity of each plot $(50 \times 50 \mathrm{~m})$. The number of species was used to calculate species richness, and $H$ and $E$ were computed using the formula below:

Shannon-Wiener index:

$$
H^{\prime}=-\sum_{i=1}^{s} p i \operatorname{InPi}
$$


Pielou's evenness index:

$$
E=\frac{H}{\ln S}
$$

Simpson diversity index:

$$
D=1-\sum_{i=1}^{s}(P i)^{2}
$$

where $S$ is the total number of species in the plots under investigation, and Pi denotes the relative richness of abundance of species $(i)$ in the total number of species.

Dominant species were determined as species with an important value (IV) greater than 1.

The Importance Value Index (IVI) was calculated using the following criteria:

Important value index (IVI) $=$ Relative density + Relative frequency + Relative dominance

Firstly, we derived a sample size formula for stratified Fisher's exact (1935) test using the values of the same input parameters as Mantel-Haenszel's test by Jung et al. [34]. Secondly, Wilcoxon's rank test was used to evaluate the variations in species diversity, evenness, and soil nutrients from 9 random plots $(50 \times 50 \mathrm{~m})$ having 64 subplots $(20 \times 20 \mathrm{~m})$ in the years 2012 and 2019.

Thirdly, simple regression was used to measure the relationship between plant diversity and soil conditions. The optimal model was determined through statistical model comparison approaches; R2 and the difference between the $\beta$ coefficient values are examples of such metrics. The soil nutrient effects on the most common or dominant species were evaluated by using canonical correspondence analysis (CCA) at each stage of recovery. Finally, principal component analysis (PCA) was performed to identify the strongest correlation and covariation among soil variables spanning seven years. The graphical presentation was carried out by using "ggplot2", "stat", and "agricole" for Figure 1, factominer and factoextra packages for Figure 2, factoextra package for Figure 3, and "stat" package for Supplementary Table S1 in $R$ software 2.9.3 [35].
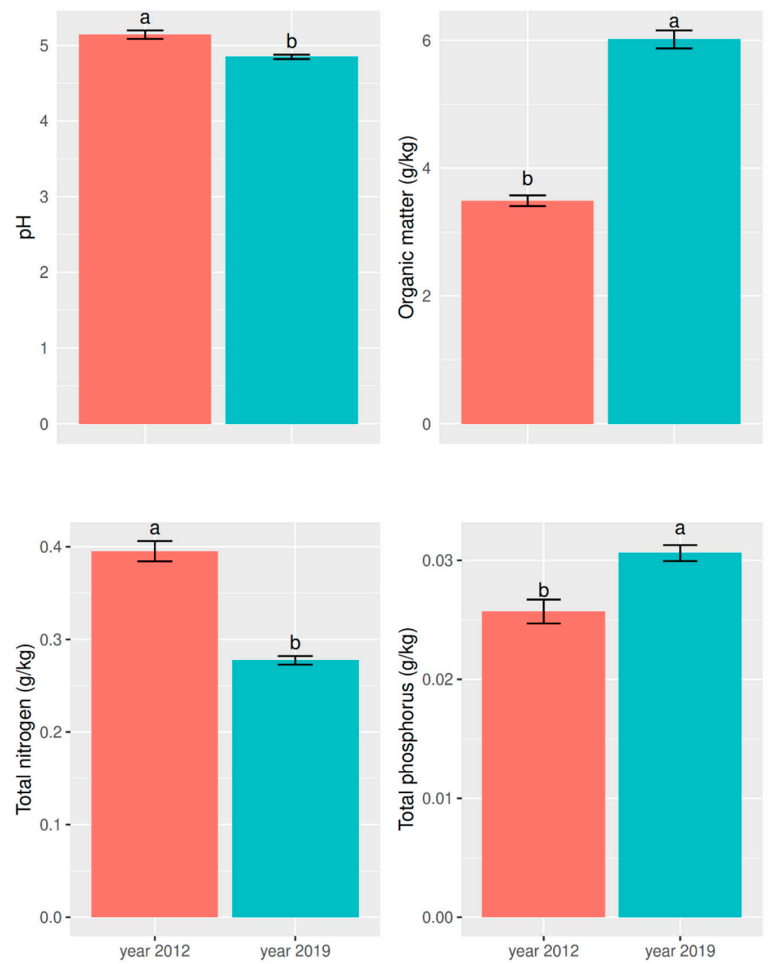

Figure 1. Bar plot showing soil $\mathrm{pH}$ values and organic matter, total nitrogen, and total phosphorus concentrations in 2012 and 2019. Error bars are the standard errors. Different letters indicate significant differences between the investigation years according to Wilcoxon's rank test $(p<0.05)$. 

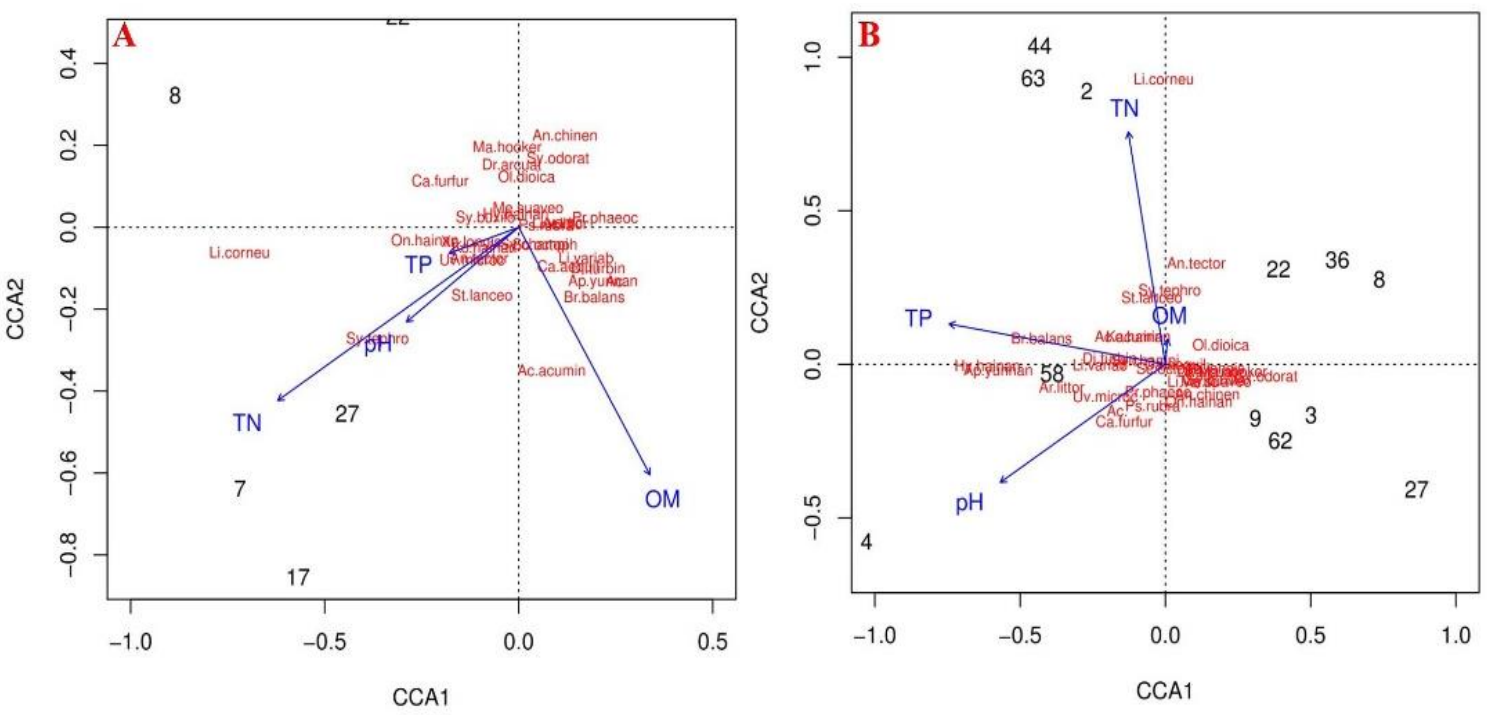

Figure 2. Canonical correspondence analysis (CCA) between dominant species richness (red species abbreviation) and soil nutrients (blue nutrient abbreviation) in the secondary tropical evergreen monsoon forest in 2012 (A) and 2019 (B). OM, organic matter; TN, total nitrogen; TP, total phosphorus.

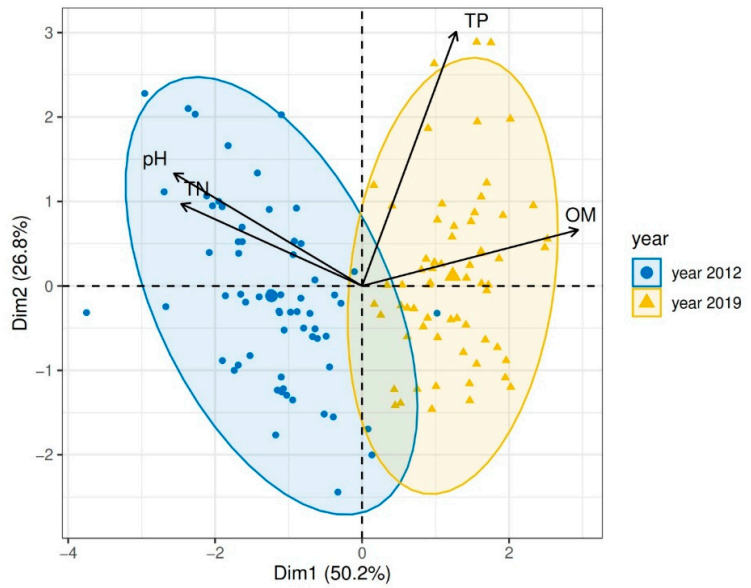

Figure 3. Principal component analysis (PCA) of soil variables in two different years (2012 and 2019). Blue and yellow dots show the sites. $\mathrm{pH}$, soil $\mathrm{pH}$; OM, organic matter; $\mathrm{TN}$, total nitrogen; TP, total phosphorus.

\section{Results}

3.1. Patterns of Soil Nutrients and Effects on Plant Diversity in Two Different Years

In the forest community of TNNR, the $\mathrm{pH}(\mathrm{F}=22.5, p=0.01)$ and $\mathrm{TN}(\mathrm{F}=98.54$, $p=0.01)$ significantly decreased, while $\mathrm{OM}(\mathrm{F}=239.86, p=0.01)$ and $\mathrm{TP}(\mathrm{F}=16.44, p=0.01)$ significantly increased from 2012 to 2019 (Figure 1).

The Shannon-Wiener index $(W=6100.0, p=0.01)$, Simpson index $(W=5907.0, p=0.01)$ and species richness $(W=6462.5, p=0.00)$ were significantly higher in 2012 than in 2019 (Table 1). Furthermore, Pielou's evenness $(W=4608.0, p=0.63)$ remained the same in the two different periods and was highly non-significant. 
Table 1. Comparison of species richness, Shannon-Wiener Index, species evenness, and Simpson index between the two years (2012 and 2019). Values are mean \pm standard deviation, $N=64$.

\begin{tabular}{ccccc}
\hline \multirow{2}{*}{ Parameters } & \multicolumn{2}{c}{ Two Years' Difference } & \multicolumn{2}{c}{ Wilcoxon's Rank Test } \\
\cline { 2 - 5 } & $\mathbf{2 0 1 2}$ & $\mathbf{2 0 1 9}$ & $\boldsymbol{W}$ & $\boldsymbol{p}$-Value \\
\hline Shannon-Wiener index & $3.21 \pm 0.02$ & $2.84 \pm 0.09$ & 6100.0 & 0.01 \\
Simpson index & $0.94 \pm 0.01$ & $0.88 \pm 0.02$ & 5907.0 & 0.01 \\
Species richness & $45.07 \pm 0.8$ & $35.92 \pm 1.56$ & 6462.5 & 0.00 \\
Pielou's evenness & $0.85 \pm 0.01$ & $0.85 \pm 0.01$ & 4608.0 & 0.63 \\
\hline
\end{tabular}

Based on multiple regression analysis, we found that soil TP was the strongest predictor for plant diversity in 2012, whereas soil TN was the strongest predictor for species diversity in 2019. The $\mathrm{R} 2$ values showed the greatest strength for the species richness in both years (Supplementary Table S1).

\subsection{Patterns of Dominant Species and Effects of Soil Nutrients on Dominant Species (Based on} Their Basal Area and Abundance)

We collected a total of 203 species from 57 families in 2019, and 218 total species of 71 families in 2012. In 2012, S. octophylla, A. oligophlebia, S. buxifolium, A. acuminatissima, O. dioica, E. sylvestri, S. buxifolioideum, X. longispinosa, P. phaeocosticta, and L. variabilis were dominant species based on their basal area, (Supplementary Table S2). In 2019, H. hainanensis, A. acuminatissima, A. chinensis, C. furfuracea, S. octophylla, K. hainanense, $O$. dioica, S. buxifolium, L. verticillate, and A. oligophlebia were dominant species (Supplementary Table S3).

Dominating species abundance was closely related to TN and OM in 2012 (Figure 2A), and to TP and TN in 2019 (Figure 2B), using canonical correlation analysis (CCA).

\subsection{Variation in Soil Nutrients in Two Different Years}

In Figure 3, plot numbers are represented by circular and triangular symbols representing the years 2012 and 2019, respectively, and soil nutrient indices are plotted as vectors. These vectors are pinned at the origin of PCs (Dim $1=50.2 \%$ and Dim $2=26.8 \%$ ) (Figure 3 ). In the two different years, 2012 and 2019 heterogeneity levels were recorded for different sites. In 2012, pH, TN, and OM had a greater contribution to PC2 (Dim2), while TP had little influence on Dim1. Moreover, OM and TN have a negative relationship in both years. There is no significant difference in soil abiotic properties. Soil TP and OM significantly improved in 2019 and had a strong positive correlation. The soil $\mathrm{pH}$ was closely related to TN and had a positive association in 2012.

\section{Discussion}

\subsection{Patterns of Soil Nutrients and Their Effects on Species Diversity in Two Different Sampling Years}

The changes in soil properties affect the soil functions such as nutrient transportation and redistribution to various parts of the plant for growth and development [36]. Therefore, $\mathrm{pH}$ and soil nutrients, including $\mathrm{N}$ and $\mathrm{P}$, are important regulators of plant growth (e.g., shoot and root growth) [37]. From grassland to the primary forest stage, an increase in organic matter (Figure 1) may lead to increased richness [30]. Similarly, Long et al. [30] found that the concentration of OM was increased in the tropical monsoonal forest. Our observations are consistent with these findings, as soil OM increased from 2012 to 2019, and TN and pH decreased in 2019 as compared to 2012 (Figure 1).

Soil $\mathrm{P}$ is the main nutrient balancing plant productivity and better development in the forestland ecosystem [38]. The species adapted to low-phosphorus soils grow fast in tropical forests $[39,40]$. Total phosphorus is generally a limiting factor, because the $\mathrm{H}^{2} \mathrm{PO}^{4}$-anion forms poorly soluble compounds with $\mathrm{Al} 3+$ and $\mathrm{Fe} 3+$ in tropical soils. As a result, topsoil soluble phosphorus concentrations remain low. Furthermore, the regular loss of phosphorus during long-term soil and ecosystem development may result in very 
low total phosphorus levels [41,42]. Our results also show that the total soil phosphorus was decreased (Figure 1) in the year 2012 with higher species diversity and not significantly correlated with diversity attributes in 2012 (Supplementary Table S1).

Soil $\mathrm{pH}$ has been demonstrated in several studies to have a significant effect on plant diversity, and the combination of acidic soil and low-temperature climatic conditions limits the distribution of many tropical species [43]. Furthermore, Liu et al. [20] showed the correlation between the species distribution and soil $\mathrm{pH}$ at the three sites. Overall, low soil nutrients and soil $\mathrm{pH}$ may be limiting factors for the decline in species diversity (Table 1) [20]. Our findings support the nutrient gradient hypothesis, as general mechanisms underlying the change patterns in soil properties such as $\mathrm{pH}$ were lower from 2012 to 2019 (Figure 1). Steege et al. [44] reported a decrease in plant diversity in tropics. A similar decreasing trend in plant diversity was observed in our study in 2019. This decrease in plant diversity may possibly be due to various natural or anthropogenic factors, including invasive species dominance, habitat fragmentation, and deforestation (Table 1) [45].

It is usually hypothesized that $\mathrm{N}$ availability in lowland tropical forest soils exceeds plant requirements [46]. This hypothesis was challenged by two ecologists [47] who concluded that $\mathrm{N}$ limitation was equally strong in temperate and tropical forests. Our findings also demonstrated TN limitation for tropical forest communities in 2019 as compared to 2012. In addition, neither total soil nitrogen nor its available mineral forms of ammonium and nitrate decreased over time. Because forest biomass was larger in older plots, the lack of a noticeable drop in soil $\mathrm{N}$ could be related to litter accumulation over time since abandonment. Our results also identified this, where the TN was not decreased (Figure 1) in 2012 and it was negatively correlated with species diversity (Supplementary Table S1). Organic matter contains many key elements, i.e., nitrogen. As a result, increases in OM and $\mathrm{TN}$ are expected to help to increase species diversity. In contrast, the limited resources of soil nutrients such as total nitrogen will limit plant growth and influence community diversity [48].

\subsection{Soil Properties Differences in Two Different Years}

In the assessment of the integrated soil fertility quality index (SFQI $I_{P C A}$ ), principal component analysis (PCA) has been widely used [49]. According to PCA, such variations in the relative significance of a strategy could be mediated by changes in soil conditions [50]. Soil nutrients, such as soil TP, contributed positively to the primary axis of PCA [50]. On the other hand, Chen et al. [49] reported that first PC (PC1) was highly correlated with TN. Hence, in the current study, PCA loadings also indicated that the first PC (PC1) was highly positively correlated with TP while PC (PC1) was not correlated with TN (Figure 3).

\subsection{Plant Species Diversity and Dominant Species Role in Two Different Sampling Years and Their} Relationship to Soil Nutrients (2012 and 2019)

A strong positive and significant correlation was found between tree species richness with TN, TP, and OM in tropical coastal secondary forests in southern China [13]. Higher concentrations of TN and OM can maintain the loss of soil nitrogen and increase the diversity of species and the richness of dominant species [51]. We concluded that availability of soil nutrients is a key element inducing species distribution. Hence, our findings also show that the abundance of dominant species was greatly influenced by soil nutrients in the two different years (soil TN, TP, and OM) (Figure 2). In 2012, soil nutrients such as OM and TN contributed more with dominant species (Figure 2A). In 2019, the soil nutrients TN and TP contributed more with dominant species (Figure 2B). The same results were found in that diversity and richness of dominant species decreased at later stage of succession due to severe human activities such as slash and burn, as well as changing natural environmental conditions, i.e., typhoon disturbances [13], on Hainan Island in southern China. The identities of dominant species and their influence on their environments are key to linking diversity patterns to ecosystem function, as well as predicting impacts of species loss and other aspects of global change on ecosystems [52]. Likewise, the important value index (IVI) of dominated 
species was found in recent studies, proving that each species has its own role in promoting the balance of the ecosystem [53], and important values were used to classify major and constructive species to vegetation sites in different years. Furthermore, in 2012, we also determined the important value index (IVI) of the following dominant species based on their basal area: S. octophylla, A. oligophlebia, S. buxifolium, A. acuminatissima, O. dioica, E. sylvestri, S. buxifolioideum, X. longispinosa, P. phaeocosticta, and L. variabilis (Supplementary Table S2). In 2019, we estimated the important value index (IVI) of the following dominant species: $H$. hainanensis, A. acuminatissima, A. chinensis, C. furfuracea, S. octophylla, K. hainanense, O. dioica, S. buxifolium, L. verticillate, and A. oligophlebia (Supplementary Table S3).

Species richness is usually controlled by the same period of climate within the global biosphere [54], which helps to stabilize the hydraulic energy system in the ecological period [55]. In addition, our results showed that plant diversity and abundance of species were dominant in 2012. Individual dominating species were found in the tropical monsoonal forest during the two different periods of time, which could be due to changes in predominant species responses to soil nutrients (Figure 2) [56]. The decline in the dominant species in the two different years changed; the species with greater decline ratios may be removed in the future for forest restoration. Moreover, it is reported that the species with lower decline ratios possibly conserve for longer periods of time [57]. Nonetheless, these species possibly create enough space for dominant species during their maturity. However, the forest has a very complicated ecosystem, and the ecological drivers affecting species co-occurrence and replacement during the restoration period may be highly diverse [58] Therefore, further research is needed to gain insight into the species co-occurrence techniques during second-growth species forest restoration processes.

\section{Significance for Conservation}

The tropical secondary forest in TNNR is well protected and had high species richness in 2012 (over 70 species in $2500 \mathrm{~m}^{2}$ ). Since TNNR was established in 1983, forest have helped understand the usefulness of protection. The plant species diversity in the secondgrowth forest suggests that restoration was not advanced in 2012 and 2019 in this area on a large scale because of poor management practices and natural disturbances. Furthermore, evidence showed that soil nutrients (OM and $\mathrm{TN})$ are closely related to the dominant species in 2012, which suggests that soil nutrient management or restoration would be a top driver in the management methods of these protected areas. Lastly, the richness of the most common or dominant species with time progression can help us identify the most suitable tree species for restoring coastal windbreaks in the area.

Supplementary Materials: The following supporting information can be downloaded at: https:/ / www.mdpi.com/article/10.3390/f13030376/s1, Table S1: Regression analysis between plant diversity and environmental variables (2012\&2019); Table S2: Species IVIs for year 2012; Table S3: Species IVIs for year 2019.

Author Contributions: M.Y. and W.L. conceived the research ideas; G.F. (Gaopan Fan) and X.Z. classified the vegetation data sets and wrote the paper with contributions; M.Y. prepared and analyzed the environmental variables; W.L. and G.F. (Guang Feng) rigorously checked and revised the manuscript; all authors discussed the results and commented on the manuscript. All authors have read and agreed to the published version of the manuscript.

Funding: This research was funded by the National Key Research and Development Program of China (2021YFD2200403).

Data Availability Statement: All the data supporting the results of this work can be found in the Supplements.

Acknowledgments: We are thankful to our lab fellows for their kind cooperation, and especially to Farhan Akhter (The Islamia University of Bahawalpur, Punjab, Pakistan) and Umair Ahmed (Huazhong Agricultural University, Wuhan, China), who supported us throughout this project.

Conflicts of Interest: The authors declare no conflict of interest. 


\section{References}

1. Fujii, K.; Shibata, M.; Kitajima, K.; Ichie, T.; Kitayama, K.; Turner, B.L. Plant-soil interactions maintain biodiversity and functions of tropical forest ecosystems. Ecol. Res. 2018, 33, 149-160. [CrossRef]

2. Liu, X.; Tan, N.; Zhou, G.; Zhang, D.; Zhang, Q.; Liu, S.; Chu, G.; Liu, J. Plant diversity and species turnover co-regulate soil nitrogen and phosphorus availability in Dinghushan forests, southern China. Plant Soil 2021, 464, 257-272. [CrossRef]

3. Trindade, C.R.T.; Landeiro, V.L.; Schneck, F. Macrophyte functional groups elucidate the relative role of environmental and spatial factors on species richness and assemblage structure. Hydrobiologia 2018, 823 Pt 2, 217-230. [CrossRef]

4. Dong, S.; Sha, W.; Su, X.; Zhang, Y.; LI, S.; Gao, X.; Liu, S.; Shi, J.; Liu, Q.; Hao, Y. The impacts of geographic, soil and climatic factors on plant diversity, biomass and their relationships of the alpine dry ecosystems: Cases from the Aerjin Mountain Nature Reserve, China. Ecol. Eng. 2019, 127, 170-177. [CrossRef]

5. Deyn, D.E.; Raaijmakers, G.B.; Van, C.E.; Der Putten, W.H. Plant community development is affected by nutrients and soil biota. J. Ecol. 2004, 92, 824-834. [CrossRef]

6. Perroni-Ventura, Y.; Montaña, C.; García-Oliva, F. Relationship between soil nutrient availability and plant species richness in a tropical semi-arid environment. J. Veg. Sci. 2006, 17, 719-728. [CrossRef]

7. Bulenga, G.B.; Maliondo, S.M.S.; Katani, J.Z. Relationships between tree species diversity with soil chemical properties in semi-dry Miombo Woodland ecosystems. Tanzan. J. For. Nat. Conserv. 2021, 90, 1-17.

8. Odum, E.P. The Strategy of Ecosystem Development. Science 1969, 164, 262-270. [CrossRef]

9. Turner, B.L.; Brenes-Arguedas, T.; Condit, R. Pervasive phosphorus limitation of tree species but not communities in tropical forests. Nature 2018, 555, 367-370. [CrossRef]

10. Zalamea, P.; Turner, B.L.; Winter, K.; Jones, F.A.; Sarmiento, C.; Dalling, J.W. Seedling growth responses to phosphorus reflect adult distribution patterns of tropical trees. New Phytol. 2016, 212, 400-408. [CrossRef]

11. Jakovac, C.C.; Bongers, F.; Kuyper, T.W.; Mesquita, R.C.G.; Pena-Claros, M. Land use as a filter for species composition in Amazonian secondary forests. J. Veg. Sci. 2016, 27, 1104-1116. [CrossRef]

12. Grime, J.P. Plant Strategies and Vegetation Processes, 1st ed.; John Wiley \& Sons: Hoboken, NJ, USA, $1979 ;$ ISBN 9780471996927.

13. Long, C.; Yang, X.; Long, W.; Li, D.; Zhou, W.; Zhang, H. Soil nutrients influence plant community assembly in two tropical coastal secondary forests. Trop. Conserv. Sci. 2018, 11, 1-9. [CrossRef]

14. Gaston, K.J. Common ecology. Bioscience 2011, 61, 354-362. [CrossRef]

15. Neri, A.V.; Schaefer, C.E.G.R.; Silva, A.F.; Souza, A.L.; Ferreira-Junior, W.G.; Meira-Neto, J.A.A. The influence of soils on the floristic composition and community structure of an area of Brazilian cerrado vegetation. Edinb. J. Bot. 2012, 69, 1-27. [CrossRef]

16. Janssen, F.; Peters, A.; Tallowin, J.R.B.; Bakker, J.P.; Bekker, R.M.; Fillat, F.; Oomes, M.J.M. Relationship between soil chemical factors and grassland diversity. Plant Soil 1998, 202, 69-78. [CrossRef]

17. Kumar, J.I.; Kumar, R.N.; Bhoi, R.K.; Sajish, P.R. Tree species diversity and soil nutrient status in three sites of tropical dry deciduous forest of western India. Trop. Ecol. 2010, 51, 273-279.

18. Nadeau, M.B.; Sullivan, T.P. Relationships between plant biodiversity and soil fertility in a mature tropical forest, Costa Rica. Int. J. For. Res. 2015, 2015, 732946. [CrossRef]

19. Cárate-Tandalla, D.; Camenzind, T.; Leuschner, C.; Homeier, J. Contrasting species responses to continued nitrogen and phosphorus addition in tropical montane forests tree seedlings. Biotropica 2018, 50, 234-245. [CrossRef]

20. Liu, H.; Chen, Q.; Liu, X.; Xu, Z.; Dai, Y.; Liu, Y.; Chen, Y. Variation patterns of plant composition/diversity in Dacrydium pectinatum communities and their driving factors in a biodiversity hotspot on Hainan Island, China. Glob. Ecol. Conserv. 2020, 22, e01034. [CrossRef]

21. John, R.; Dalling, J.W.; Harms, K.E.; Yavitt, J.B.; Stallard, R.F.; Mirabello, M.; Hubbell, S.P.; Valencia, R.; Navarrete, H.; Vallejo, M.; et al. Soil nutrients influence spatial distributions of tropical tree species. Proc. Natl. Acad. Sci. USA 2007, 104, 864-869. [CrossRef]

22. Fayolle, A.; Engelbrecht, B.; Freycon, V.; Mortier, F.; Swaine, M.; Rejou Mechain, M.; Doucet, J.-L.; Fauvet, N.; Cornu, G.; Gourlet-Fleury, S. Geological substrates shape tree species and trait distributions in African moist forests. PLoS ONE 2012, 7, e42381. [CrossRef]

23. Figueiredo, F.O.; Zuquim, G.; Tuomisto, H.; Moulatlet, G.M.; Balslev, H.; Costa, F.R. Beyond climate control on species range: The importance of soil data to predict distribution of Amazonian plant species. J. Biogeogr. 2018, 45, 190-200. [CrossRef]

24. Werden, L.K.; Becknell, J.M.; Powers, J.S. Edaphic factors, successional status and functional traits drive habitat associations of trees in naturally regenerating tropical dry forests. Funct. Ecol. 2018, 32, 2766-2776. [CrossRef]

25. Augusto, L.; Achat, D.L.; Jonard, M.; Vidal, D.; Ringeval, B. Soil parent material-A major driver of plant nutrient limitations in terrestrial ecosystems. Glob. Change Biol. 2017, 23, 3808-3824. [CrossRef] [PubMed]

26. Medvigy, D.; Wang, G.; Zhu, Q.; Riley, W.J.; Trierweiler, A.M.; Waring, B.G.; Xu, X.; Powers, J.S. Observed variation in soil properties can drive large variation in modelled forest functioning and composition during tropical forest secondary succession. New Phytol. 2019, 223, 1820-1833. [CrossRef]

27. Situ, S.J. Study on the Historical Land Exploitation of Hainan Island; Hainan Press: Haikou, China, 1987.

28. Waring, B.G.; Becknell, J.M.; Powers, J.S. Nitrogen, phosphorus, and cation use efficiency in stands of regenerating tropical dry forest. Oecologia 2015, 178, 887-897. [CrossRef]

29. Huang, J.; Wang, C.; Qi, L.; Zhang, X.; Tang, G.; Li, L.; Guo, J.; Jia, Y.; Dou, X.; Lu, M. Phosphorus is more effective than nitrogen in restoring plant communities of heavy metals polluted soils. Environ. Pollut. 2020, 266, 115259. [CrossRef] 
30. Long, W.; Yang, X.; Li, D. Patterns of species diversity and soil nutrients along a chrono sequence of vegetation recovery in Hainan Island, South China. Ecol. Res. 2012, 27, 561-568. [CrossRef]

31. Wu, Z.Y. Vegetation in China; Science Press: Beijing, China, 1995.

32. Jobba'gy, E.G.; Jackson, R.B. The distribution of soil nutrients with depth: Global patterns and the imprint of plants. Biogeochemistry 2001, 53, 51-77. [CrossRef]

33. Anderson, J.M.; Ingram, J.S.I. Tropical Soil Biology and Fertility: A Handbook of Methods; C.A.B. International: Aberystwyth, UK, 1989; Volume 157, p. 265.

34. Jung, S.-H. Stratified Fisher's exact test and its sample size calculation. Biom. J. 2014, 56, 129-140. [CrossRef]

35. R Core Development Team (Ed.) R: A Language and Environment for Statistical Computing; R Foundation for Statistical Computing: Vienna, Austria, 2016; Available online: www.R-project.org/ (accessed on 10 February 2015).

36. Agbu, P.A.; Olson, K.R. Spatial variability of soil properties in selected Illinois Mollisols. Soil Sci. 1990, 150, 777-786. [CrossRef]

37. Li, X.; Zhang, X.; Wu, J.; Shen, Z.; Zhang, Y.; Xu, X.; Fan, Y.; Zhao, Y.; Yan, W. Root biomass distribution in alpine ecosystems of the northern Tibetan Plateau. Environ. Earth Sci. 2011, 64, 1911-1919. [CrossRef]

38. Chen, C.R.; Condron, L.M.; Davis, M.R.; Sherlock, R.R. Effects of afforestation on phosphorus dynamics and biological properties in a New Zealand grassland soil. Plant Soil 2000, 220, 151-163. [CrossRef]

39. Kooyman, R.M.; Laffan, S.W.; Westoby, M. The incidence of low phosphorus soils in Australia. Plant Soil 2017, 412, 143-150. [CrossRef]

40. Smithsonian Tropical Research Institute. Diverse Tropical Forests Grow Fast Despite Widespread Phosphorus Limitation. ScienceDaily. 7 March 2018. Available online: www.sciencedaily.com/releases/2018/03/180307153944.htm (accessed on 7 March 2018).

41. Bohn, H.; Mcneal, B.; O'Connor, G. Soil Chemistry, 3rd ed.; Wiley: New York, NY, USA, 2001.

42. Vitousek, P.M.; Porder, S.; Houlton, B.Z.; Chadwick, O.A. Terrestrial phosphorus limitation: Mechanisms, implications, and nitrogen-phosphorus interactions. Ecol. Appl. 2010, 20, 5-15. [CrossRef]

43. Jiang, Y.; Zang, R.; Letcher, S.G.; Ding, Y.; Huang, Y.; Lu, X.; Huang, J.; Liu, W.; Zhang, Z. Associations between plant composition/diversity and the abiotic environment across six vegetation types in a biodiversity hotspot of Hainan Island, China. Plant Soil 2016, 403, 21-35. [CrossRef]

44. ter Steege, H.; Pitman, N.C.A.; Killeen, T.J.; Laurance, W.F.; Peres, C.A.; Guevara, J.E.; Salomão, R.P.; Castilho, C.V.; Amaral, I.L.; de Almeida Matos, F.D.; et al. Estimating the global conservation status of more than 15,000 Amazonian tree species. Sci. Adv. 2015, 1. [CrossRef]

45. Kettle, C.J.; Koh, L.P. (Eds.) Global Forest Fragmentation; CABI: Wallingford, UK, 2014; ISBN 9781780642031.

46. Hedin, L.O.; Brookshire, E.N.J.; Menge, D.N.L.; Barron, A.R. The Nitrogen Paradox in Tropical Forest Ecosystems. Annu. Rev. Ecol. Evol. Syst. 2009, 40, 613-635. [CrossRef]

47. LeBauer, D.S.; Treseder, K.K. Nitrogen limitation of net primary productivity in terrestrial ecosystems is globally distributed. Ecology 2008, 89, 371-379. [CrossRef]

48. Avolio, M.L.; Forrestel, E.J.; Chang, C.C.; La Pierre, K.J.; Burghardt, K.T.; Smith, M.D. Demystifying dominant species. New Phytol. 2019, 223, 1106-1126. [CrossRef]

49. Chen, J.; Qu, M.; Zhang, J.; Xie, E.; Huang, B.; Zhao, Y. Soil fertility quality assessment based on geographically weighted principal component analysis (GWPCA) in large-scale areas. CATENA 2021, 201, 105197. [CrossRef]

50. Hernández-Vargas, G.; Sánchez-Velásquez, L.R.; López-Acosta, J.C.; Noa-Carrazana, J.C.; Perroni, Y. Relationship between soil properties and leaf functional traits in early secondary succession of tropical montane cloud forest. Ecol. Res. 2019, 34, 213-224. [CrossRef]

51. Whittaker, R.J.; Bush, M.B.; Richards, K. Plant Recolonization and Vegetation Succession on the Krakatau Islands, Indonesia. Ecol. Monogr. 1989, 59, 59-123. [CrossRef]

52. Schmidt, M.; Veldkamp, E.; Corre, M.D. Tree species diversity effects on productivity, soil nutrient availability and nutrient response efficiency in a temperate deciduous forest. For. Ecol. Manag. 2015, 338, 114-123. [CrossRef]

53. Chala, D.; Brochmann, C.; Psomas, A.; Ehrich, D.; Gizaw, A.; Masao, C.A.; Zimmermann, N.E. Good-bye to tropical alpine plant giants under warmer climates? Loss of range and genetic diversity in Lobelia rhynchopetalum. Ecol. Evol. 2016, 6, 8931-8941. [CrossRef] [PubMed]

54. Vázquez-Rivera, H.; Currie, D.J. Contemporaneous climate directly controls broad-scale patterns of woody plant diversity: A test by a natural experiment over 14,000 years. Glob. Ecol. Biogeogr. 2015, 24, 97-106. [CrossRef]

55. Kreft, H.; Jetz, W. Global patterns and determinants of vascular plant diversity. Proc. Natl. Acad. Sci. USA 2007, 104, 5925-5930. [CrossRef] [PubMed]

56. Whitfeld, T.J.; Lasky, J.R.; Damas, K.; Sosanika, G.; Molem, K.; Montgomery, R.A. Species richness, forest structure, and functional diversity during succession in the New Guinea lowlands. Biotropica 2014, 46, 538-548. [CrossRef]

57. Lu, X.; Zang, R.; Ding, Y.; Huang, J. Partitioning the functional variation of tree seedlings during secondary succession in a tropical lowland rainforest. Ecosphere 2018, 9, e02305. [CrossRef]

58. Li, C.; Zhao, L.; Sun, P.; Zhao, F.; Kang, D.; Yang, G.; Han, X.; Feng, Y.; Ren, G. Deep Soil C, N, and P Stocks and Stoichiometry in Response to Land Use Patterns in the Loess Hilly Region of China. PLoS ONE 2016, 11, e0159075. [CrossRef] 